\title{
"I riro whenua atu me hoki whenua mai": The return of land and the Waikato-Tainui raupatu settlement
}

\author{
MARTIN FISHER
}

\begin{abstract}
The Waikato-Tainui raupatu settlement signed in 1995 focused on the return of land to address grievances related to the war and confiscation that marked the Waikato region in the 1860s. Negotiations regarding the return of land focused on the tribal entity into which lands would be vested, which specific lands they would be returned and in what legal form they would be utilised. The negotiations regarding the return of land to Waikato-Tainui represented a situation under which the Crown's power was reinvented rather than weakened. Compromises were made and some land was returned but it was under the Crown's framework and overall control.
\end{abstract}

\section{Introduction}

The importance of land to Māori has been paramount throughout New Zealand's history. In the Māori version of the Treaty of Waitangi, Article Two guaranteed to Māori "te tino rangatiratanga," what Claudia Orange describes as the unqualified exercise of their chieftanship, over "ratou w[h]enua o ratou kainga me o ratou taonga katoa," their lands, villages and treasures. The English version of Article Two of the Treaty of Waitangi guaranteed to Māori "the full exclusive undisturbed possession of their Lands and Estates." The intimate connections between the people ("tangata") and land ("whenua") have been signified in a number of different Māori proverbs such as: "Te toto o te tangata he kai, te oranga o te tangata he whenua" ("The lifeblood of a person is derived from food; the livelihood of a people depends on land"), and "Toitu he whenua, whatungarongaro he tangata" ("The land remains after the people have gone"). ${ }^{2}$ Paerau Warbrick has commented that to Māori the "whenua ... is linked with people and the greater cosmos, and incorporates the corporeal as well as the ethereal."3 Unsurprisingly, claims to land have been a central part of the New Zealand Treaty settlement process.

Within the framework of the importance of land to Māori, the return of land was a key component in Waikato-Tainui's raupatu (confiscation) Treaty settlement (1989-1995) that is embodied in the principle that governed their negotiations for decades: "I riro whenua atu me hoki whenua mai" - as land was taken so land must be returned. For Waikato-Tainui the confiscation of their lands was a vivid symbol of the way in which their mana whenua or authority over land was directly challenged. This article argues, much like Michael J. Stevens does in relation to the Ngāi Tahu settlement, that the negotiations regarding the return of land to Waikato-Tainui represented a situation under which the Crown's power was reinvented rather than weakened. ${ }^{4}$ Compromises were made and some land was returned but it was under the Crown's framework and overall control.

The return of land was marked by Waikato-Tainui's efforts to ensure the land could not be alienated again in the future. In 1991 and 1993 two former military bases at Hopuhopu and Te Rapa were slated for return to Waikato-Tainui. Although Waikato-Tainui occupied both bases earlier, they were not legally transferred until settlement legislation was passed in $1995 .^{5}$ Waikato-Tainui sought legal mechanisms to retain returned land such as the restoration of land under a form of inalienable customary title rather than fee simple title. Waikato-Tainui also sought the return of lands without marginal strips. ${ }^{6}$ Waikato-Tainui's settlement was ultimately restricted to grievances solely regarding the confiscation of land and was not marked by the environmental management issues that at times dominated nearly all other negotiations since 
they were the first iwi-based negotiation to complete a settlement. Nonetheless Waikato-Tainui attempted to have Department of Conservation (DoC) land included in its settlement, or at least a co-management role with DoC for the land in the Waikato-Tainui rohe, but there was similar opposition both within and outside government from conservation interests. In addition to conservationists, Waikato-Tainui also had to contend with other third-parties - former owners of Crown land taken under the Public Works Act - who delayed the return of Crown land in the Waikato-Tainui settlement, but that is an issue of some complexity that will have to be addressed in detail elsewhere. This article will analyse the negotiations regarding the return of specific lands at Hopuhopu and Te Rapa as well as Department of Conservation lands, the establishment of Waikato-Tainui's land-bank, and the legal form in which land would be returned. Although the Crown had overwhelming control of the wider process, Waikato-Tainui were able to regain some lands and enhance in some ways their rangatiratanga or selfdetermination.

\section{The context of the negotiations}

Waikato-Tainui sought to halt the alienation of Crown lands in its tribal region in the wake of the State Owned Enterprises Act 1986. In the NZMC v. Attorney-General case the New Zealand Māori Council charged that the State Owned Enterprises Act 1986 breached the principles of the Treaty of Waitangi because the Act enabled the government to privatise land and assets, which would then become unavailable for use as compensation for Māori historical grievances. Sir Robin Cooke and his fellow justices in the Court of Appeal agreed that the legislation did breach the principles of the Treaty and forced the government to negotiate with Māori leaders to develop some safeguards that would protect land and assets from sale. ${ }^{7}$ The result was the Treaty of Waitangi (State Enterprises) Act 1988 which provided clawback mechanisms, called memorials, for land and assets that were subject to Māori claims, but their effectiveness in halting the alienation of land was in no way immediate. ${ }^{8}$

During Waikato-Tainui's scoping negotiations in mid-1989, Crown officials were informed by Waikato-Tainui negotiators that the continuing alienation of Crown land was a primary concern. The Treasury official involved in the scoping negotiations attempted to develop a system under which Waikato-Tainui would receive a warning regarding the pending alienation of Crown land and potentially halt the sale. If Waikato-Tainui sought the inclusion of the Crown land in their settlement, it would be placed in a land-bank for future use. Unfortunately there was no support for such a system for Waikato-Tainui from senior Crown officials although it is unclear what the specific rationales were. Waikato-Tainui's land-bank was not established until early 1993. Although the land-banking process was an innovative method to protect against the alienation of Crown land, the nature of the process could be frustrating for Waikato-Tainui as there were limits to the amount of land and types of land allowed in each land-bank. Damian Stone has rightly commented that Crown properties available for land-banking often consisted of the least profitable and hence least desirable Crown lands available. ${ }^{9}$ In addition, as Alan Ward has noted, it was "not easy for claimants to discern, from the information provided, what was important land" in terms of its potential profitability. ${ }^{10}$ Since Waikato-Tainui wanted all land returned there were tensions around identifying which specific lands would be returned. At times, less profitable lands such as urupa may have been sought. Many of the issues surrounding the development and operation of Waikato-Tainui's land-bank emerged from the Crown's overriding control of the land-banking process in setting the kind of lands that would be available and the total cap on each land-bank.

\section{Methodology}

Research for this article was enabled by the Office of Treaty Settlements (referred to as OTS in the references) in Wellington, which provided access to its archives. These sources were 
supplemented by the collections held by the Waikato-Tainui College of Research and Development located at Hopuhopu near Ngaruawahia. In addition, Sir Douglas Graham, the Minister of Treaty Negotiations for most of the 1990s, provided unrestricted access to his own personal files held at Archives New Zealand (Archives NZ), Wellington. As a historian employed by neither the Crown nor Waikato-Tainui, I have used all the material available to me.

Throughout the research nearly all Crown officials are unidentified. Officials do what their job description requires them to do-give advice to the Minister and the government and once decisions are made by Cabinet, implement those decisions. Any letter, memorandum or paper that was signed out to the Minister went through many hands and had managerial input and reflected an institutional view not the personal views of the authors, which is one of the reasons that almost all Crown officials have remained anonymous. Ministers, Secretaries of Ministries, principal negotiators and Waikato-Tainui advisors (where they have agreed to be named) have not been kept anonymous. Generally, documents were split into approximately four different formats: memoranda, briefing and Cabinet papers, correspondence, and minutes of meetings. These primary sources were supplemented by contemporary newspapers such as the Evening Post, Waikato Times, New Zealand Herald, the Dominion and The Press, and periodicals such as The Listener and North and South.

For the official monthly meetings, minutes were produced by both the Crown and the respective claimant negotiating group. These were subject to revisions from both sides and an agreed set of minutes were produced for each meeting. This set of minutes was the Crown's official record of the meeting. Waikato-Tainui also produced their own record of the minutes of the meeting. These were not subject to revision by the Crown and were often not shared with the Crown unless there was a substantial disagreement over a negotiation issue or over the accuracy of the Crown's version of the meeting. The Crown's minutes of meetings were always shorter than either of Waikato-Tainui's versions of the meetings. Sometimes the Crown could use just one page to provide minutes for the meeting whereas Waikato-Tainui could use up to ten pages for the exact same meeting.

At individual meetings between Graham and Waikato-Tainui Principal Negotiator Robert Mahuta there would be no record of the meeting from the Crown or from Graham himself. Graham's archive was a much more official collection that consisted of barely any of the filenotes that Mahuta kept. Mahuta kept copious notes of phone calls and meetings. One of Mahuta's advisors, Shane Solomon, was a prolific notetaker and cartoonist. Their archives provide a singular view of certain meetings because there was no evidence of the meeting from the Crown archive. The singular point of view provided by such a perspective could potentially influence the value of the source since the only information had come from that one source, but the same concern could apply to the perspectives of Crown officials.

In general, larger meetings would have more sources of information and could be corroborated in better ways. Sometimes there would be numerous different accounts of one large meeting from both the Crown and Waikato-Tainui. This would not often be the case as the best case scenario was at least one version from the Crown and one from Waikato-Tainui. Much larger meetings that involved public consultation would have publications such as newspapers producing their own accounts as well as video accounts of the signing. These types of meetings provided the best circumstances for the proliferation of sources. The changes that could be made to meeting minutes were generally a result of compromise but at least one of the early minutes in the Waikato-Tainui negotiations was altered unilaterally. When Labour Minister of Justice Bill Jeffries was involved in the negotiations in 1990, the Crown's own copy of the March meeting minutes has written on the first page that "these were altered by the Minister [Jeffries]." "It was unclear exactly which alterations had been made but luckily for that specific meeting there was also a Waikato-Tainui version of the meeting. 


\section{The return of Hopuhopu, Te Rapa and hapū dissent}

Although negotiations had begun with the Fourth Labour Government in 1989, the substantive phase did not begin until the negotiations with the Fourth National Government in late 1991. Without any detailed Treaty policy the government was often accused by Waikato-Tainui of purposefully delaying the negotiations. The Crown for its part believed that it was responding to arguments from Waikato-Tainui without any preconceived notions. Although the Crown was generally opposed to interim settlements, it was forced to placate Waikato-Tainui with various mechanisms such as offering the return of land from late 1991 onwards as a gift and gesture of goodwill. Before the two parties formally met, the Crown informed Waikato-Tainui that the decommissioned Hopuhopu Army Base was available for transfer to the iwi to meet Waikato-Tainui's principle that as land was taken so land must be returned ("i riro whenua atu me hoki whenua mai"). ${ }^{12}$

At first, Waikato-Tainui were stunned that the Crown was actually returning land and did not believe Minister of Treaty Negotiations Douglas Graham when he made the announcement at Whaataapaka marae in late $1991 .{ }^{13}$ Although the return of the base initially engendered some substantial good will between the two parties, eventually the significant financial liabilities that the base carried eroded some of that good will. ${ }^{14}$ These financial liabilities resulted from the dilapidated state of the houses and buildings located on the land, the removal of items as basic as the kitchen sinks in all houses and buildings, and the contamination of land and buildings from old ammunition stocks. When Waikato-Tainui advisors complained to the Crown about the excessive costs of the due diligence the iwi had conducted prior to occupation of the sites, Crown officials meekly replied that no promises had ever been made about the state in which land and improvements would be returned, only that they would be transferred. ${ }^{15}$

Heta Tarawhiti of Waikato-Tainui hapū Ngāti Whawhakia had originally gifted the land at Hopuhopu to the Anglican Church in 1853 for educational purposes. The area was initially used to build a Church and school that local Māori children attended. Once the wars of the 1860s developed, the area was abandoned. ${ }^{16}$ The Anglican Church retained ownership until it was taken under the Public Works Act during World War II. When Waikato-Tainui began expressing an interest in having Hopuhopu returned to the iwi in the late 1980s, the Anglican Church supported their endeavour. The opposition to the return of Hopuhopu to the Tainui Māori Trust Board (TMTB) was from two separate parties. The descendants of Heta Tarawhiti sought the return of the land to the original owners' descendants. The other opponents of the return were conservative elements in the National Party as well as in society in general. The Chairman of the Rotoiti branch of the National Party, Ross Baker, wrote to Prime Minister Jim Bolger demanding an explanation as to "why the Minister of Justice is giving the Hopuhopu military camp to the Tainui people?" Baker believed that Waikato-Tainui had rebelled in the 1860 s and deserved punishment. In addition he pointed to the "full and final" settlement of 1946. ${ }^{17}$ A similar complaint was made in a letter to the Waikato Times regarding the return of Hopuhopu and in a letter to Doug Graham. Bolger replied to Baker that Waikato-Tainui's claims were valid and the return of Hopuhopu was an appropriate step to take in commencing negotiations. ${ }^{18}$

Mahuta wrote in a memorandum sometime in the middle of 1991 that the question of who or what the land would be vested in remained to be decided by the TMTB, with the input of the wider Waikato-Tainui community. Did they want the land in freehold fee simple title or under Māori Land title? What were the implications for any future development at Hopuhopu? Who would they register as the owner of Hopuhopu: "[The] Trust Board, Ngā Marae Toopu, [the] descendants of the original owners, Te Wherowhero?"19 Mahuta was going to seek a kaumatua hui to seek direction on these points. Mahuta's opinion on the issue of alienability was influenced by the research conducted at the Centre for Maaori Studies and Research (CMSR) at the University of Waikato of which he was the Director. Investigations of 
international experiences of Treaty settlement processes in Alaska, Canada and the United States strongly influenced his desire for inalienable title. The for-profit corporations established after the 1971 settlement with Alaskan indigenous groups was an especially strong influence on his thoughts as not only had a number of academics based in Alaska such as Nicholas Flanders been research fellows at the CMSR, but Mahuta had also spent a semester teaching at the University of Alaska in $1985 .{ }^{20}$ Later, when Treaty of Waitangi Policy Unit (ToWPU) officials asked Waikato-Tainui negotiators how people would receive benefits, Mahuta responded there would be a list of beneficiaries and that it would be up to individuals to make a choice of which of the 33 hapū they associated with. Mahuta hoped that it would "shake people out of their apathy" and emphasised later in a meeting with Crown officials that "as we suffered collectively so we should benefit collectively." 21

It was ultimately decided by TMTB that Hopuhopu (and later Te Rapa) would be vested in Te Wherowhero, the first leader of the Kingitanga, to ensure that it could not be alienated. This stemmed from the previous historical experience of various Waikato-Tainui hapū who had portions of confiscated land returned by the Compensation Court. Under the jurisdiction of the Court, rather than return the land into tribal ownership, lands were returned to individuals who could sell their lands without hindrance. Most of the lands that were eventually returned to King Pōtatau following the opening of the King Country were gradually sold by individuals during the late-nineteenth and early-twentieth century. Chief Waikato-Tainui negotiator Robert Mahuta commented in a letter to his senior legal advisor Denese Henare: "This is what we are trying to stop by vesting the land in Te Wherowhero and then appointing custodial trustees to ensure that the land is never able to be alienated as it was previously." 22 The desire by WaikatoTainui negotiators to vest settlement assets into a collective structure reflected the aspirations of Waikato-Tainui to re-assert their rangatiratanga. The decision was made following consultation with the TMTB and Ngā Marae Toopu, a collective of marae affiliated with the Kingitanga.

Waikato-Tainui negotiators wanted special legislation used to specifically vest Hopuhopu in Te Wherowhero because they were concerned that a vesting of land in an ancestor under the Māori Affairs Act 1953 was not possible. The CLO did not want to use special legislation and pressed for a vesting under the Māori Affairs Act. In November 1992 the Minister of Lands made an application to the Māori Land Court to vest Hopuhopu in Te Wherowhero. In December 1992 the Māori Land Court under Section 437 of the Māori Affairs Act vested Hopuhopu in Te Wherowhero and the TMTB as "trustee for the benefit of the Waikato Tainui tribes" until a separate Trust had been established to own and manage the land. ${ }^{23}$

Despite the orders made by the Māori Land Court in late 1992 regarding the assets received from the Crown, the vesting of Hopuhopu was still being debated within WaikatoTainui in mid-1993. By then the Crown had also offered to transfer to Waikato-Tainui the Te Rapa Air Base outside of Hamilton. ${ }^{24}$ The Te Rapa land had previously been owned by the Livingstone Family, and they were offered back the land according to the Public Works Act in mid-1992. ${ }^{25}$ Initially there were concerns expressed to ToWPU officials that a private developer would purchase the land from the Livingstone Family. ${ }^{26}$ In October 1992 a DoSLI official wrote to ToWPU that the Livingstone Family declined to purchase the Te Rapa airbase and that it would be purchased for immediate transfer to Waikato-Tainui as a partial settlement of its claims. ${ }^{27}$ Nonetheless in August 1993 a ToWPU official stated in a memorandum that the Tainui Māori Trust Board (with Crown funding) had purchased the land from the Livingstone Family. ${ }^{28}$ It is unclear how those negotiations took place and who precisely was involved but it presumably included representatives from ToWPU, the Tainui Māori Trust Board and the Livingstone Family. 
Two hapū, Ngāti Whawhakia and Ngāti Wairere, argued that since the Hopuhopu and Te Rapa military bases were located in their communities the land should be directly vested in them. Ngāti Whawhakia and Ngāti Wairere took their case to the Māori Appellate Court to attempt to halt the vesting of the land but their appeal was rejected. In 1993 the Court stated that "we accept that the Crown's intention was to return the lands as part settlement of the Tainui raupatu lands claim" and that "the settlement was with Tainui and not any individual hapū." ${ }^{29}$ The Court's decision reflected the government's preference for negotiating with larger groupings such as iwi rather than hapū, although the return of the settlement assets to hapū in theory may have been the best solution to effect rangatiratanga ${ }^{30}$ Although the Māori Appellate Court approved the return of Hopuhopu to the iwi, it did not expressly approve of the use of the Māori Affairs Act to vest the Hopuhopu lands and the matter would remain unsettled until settlement legislation was passed in October 1995. Legislation was necessary to formally underline the transfer of land due to the limits of vesting lands into a deceased ancestor. ${ }^{31}$ Waikato-Tainui advisor John Te Maru was optimistic that during the two previous years of "intense tribal debate" Waikato had reached the consensus that returned land should be vested in Te Wherowhero to ensure that the properties could never be alienated. ${ }^{32}$ Mahuta informed the Crown that the delays in reaching a settlement had severely corroded the robustness of the TMTB's mandate alluding to the challenges in the Māori Appellate Court from Ngāti Whawhakia and Ngāti Wairere dissidents. ${ }^{33}$

\section{The gradual development and eventual establishment of Waikato-Tainui's land-bank}

Outside of Hopuhopu and Te Rapa there were no further lands transferred to Waikato-Tainui during their negotiations. The development of Waikato-Tainui's land-bank was thus integral to maintaining the Crown's asset base in the tribal rohe. During Waikato-Tainui's scoping negotiations with the Fourth Labour Government in July and August 1989, a Treasury official drafted a Cabinet paper that proposed to establish the first land-bank. The Treasury official suggested a system under which the TMTB would be warned when the alienation of Crown land in the Waikato-Tainui rohe was proposed. The Trust Board would then have the opportunity to place the property in their land-bank for future use in a settlement. The draft Cabinet paper developed by the Treasury official was never finalised and sent to Cabinet. ${ }^{34}$ The litigation undertaken by the TMTB with regards to coal assets in their rohe in late August 1989, the "Coalcorp case," effectively caused a brief delay in negotiations. ${ }^{35}$ Presumably, the delay was the reason the land-bank was not developed any further in the early scoping negotiations. ${ }^{36}$

After the TMTB's victory in the Coalcorp case, Waikato-Tainui's negotiations with the Crown continued in March 1990 with Robert Mahuta and Justice Minister Bill Jeffries as respective lead negotiators. The continuing alienation of Crown land in the Waikato-Tainui rohe remained a significant concern for Waikato-Tainui negotiators. In a May 1990 report to the Core Group of Officials in the Crown Task Force on Treaty of Waitangi Issues, ToWPU officials stated that "restraint [in the alienation of Crown land] was considered necessary to comply with the view of the Court of Appeal in the Coalcorp case that any attempt to shut out in advance claims to surplus lands is not consistent with Treaty principles." After the establishment of Ngāi Tahu's land-bank in early 1990, ToWPU officials pressed Cabinet to put the land-bank system in place for Ngāi Tahu to the TMTB. ToWPU officials believed that the continuing alienation of Crown land had the potential to jeopardise the negotiations and potentially push Waikato-Tainui to re-initiate litigation to prevent the alienation of further Crown land. At the very least, the establishment of a land-bank would be construed as a gesture of goodwill from the Crown. ${ }^{37}$ Despite the recommendations of ToWPU, Cabinet refused to establish the land-bank and instead focused on developing the settlement offer that was rejected by Waikato-Tainui later in $1990 .^{38}$ 
In the absence of any system by 1991, Waikato-Tainui negotiators and advisors turned to asking for written undertakings from the new National Minister of SOEs Doug Kidd and Minister of Justice Doug Graham that Crown assets should not be sold in the Waikato raupatu rohe. Before negotiations formally began with National, Waikato-Tainui's legal advisor, Denese Henare, wrote repeatedly to warn Graham and the ToWPU Director about Crown properties that were offered for sale. ${ }^{39}$ While claimants should have been expending their time and energy on the task of negotiation, often Waikato-Tainui negotiators and advisors were forced to use their limited resources ensuring that the Crown's asset base was not diminished any further.

Graham sought to institute a land-bank system for Waikato-Tainui and other large claimant groups such as Muriwhenua and Taranaki. Formal negotiations had recommenced between the Crown and Waikato-Tainui negotiators in November 1991 and by mid-1992 ToWPU officials began to develop Waikato-Tainui's land-bank. While Waikato-Tainui appreciated the efforts being made by the Crown to develop a land-bank, the proposal still contained a presumption of sale which was not appropriate for Waikato-Tainui's land for land principle that all lands should be returned. ${ }^{40}$

Waikato-Tainui argued that the Crown should provide a diverse set of assets. WaikatoTainui wanted to include Crown Research Institute (CRI) land, Housing New Zealand (HNZ) properties, Area Health Boards and educational properties. In addition to the ability to include these lands in their land-bank, Waikato-Tainui requested that the Crown maintain its stock of HNZ properties in the rohe until negotiations were complete. ${ }^{41}$ Treasury did not agree that HNZ or Area Health Boards were Crown assets and was especially concerned about how the precedent of no net diminution would affect HNZ's commercial operations. How would HNZ follow their directives which instructed them to sell all surplus lands? As a result of the small size of the Waikato-Tainui rohe, ToWPU officials also proposed that there be no cap on the Waikato-Tainui land-bank but Treasury maintained that it was necessary for claimants to understand that the Crown's funds were not limitless. Treasury's final concern was that the Crown would be held financially responsible for deferred maintenance. Despite the negative experience of Waikato-Tainui with Hopuhopu, Treasury decided that claimants would have to receive the properties as is. In reaction to Treasury opposition, a ToWPU official responded that Waikato-Tainui "would have to have some kind of land-bank at some point." Treasury replied that it wanted a separate Treasury comment in the land-bank paper, which aided in its eventual rejection in Cabinet in mid-1992. ${ }^{42}$

After ToWPU's failed attempts at establishing a land-bank for Waikato-Tainui in 1992, Graham sought to re-engage with Treasury, Cabinet and Waikato-Tainui over the issue in early 1993. Graham wrote to Mahuta to discuss what the cap for the Waikato-Tainui land-bank might be. Although any engagement was welcomed while the negotiations were essentially in hiatus, legal advisor Denese Henare wrote to Mahuta expressing her concern about Graham's request for a discussion regarding the cap for the land-bank. Although the development of the landbank was welcomed by the Waikato-Tainui negotiators, Henare interpreted the development as the Crown approaching the issue "piece-meal." To Henare the land-bank was merely an instrument for preserving the Crown's capacity to provide reparations, not a part of the final settlement arrangement although it is unclear exactly what the difference is. At this point the Right of First Refusal (which provided Waikato-Tainui the right to be the first to purchase Crown lands as they were privatised) had yet to be developed, so Henare was not correct in the long term but in the short term her frustration stemmed from the Crown's insistence on a cap for the land-bank. ${ }^{43}$ "The Waikato position is that we will have all you have got put into the land bank, which is effectively the 163,000 acres of properties within the Crown dossier." There were also some significant concerns about receiving the lands on an "as is, where is" basis, especially as a result of the TMTB's negative experience with Hopuhopu. The good will 
established by the return of Hopuhopu had been tainted by the significant financial liabilities that the base carried upon transfer. Henare recommended that Mahuta discuss it privately with the Minister rather than a potentially "provocative letter" to ensure Graham was kept on side. ${ }^{44}$

ToWPU recommended to Cabinet that the cap for the Waikato-Tainui land-bank be set at $\$ 35$ million while Treasury advocated that it should be set at $\$ 16$ million to ensure funding was also made available for other Treaty claim settlements and land-banks. Unusually, ToWPU won out in the end. In contrast to Ngāi Tahu's land-bank, the properties also would have to be the first used in any future settlement. While it was clear that Waikato-Tainui wanted all of the Crown's remaining land placed in the land-bank, Mahuta nonetheless wrote a thankful letter to the Crown. In early May 1993 Graham replied that he was happy to inform Mahuta that the land-bank was formerly established and had a \$35 million cap, with one minor rider that was symbolic of the gulf between the power of each party in the negotiation: "The Crown reserves the right to cancel the land bank and free the properties for sale." 45

One of the first assets available for Waikato-Tainui's land-bank were 200 Electricity Corporation New Zealand (ECNZ) houses located in Meremere and Huntly. These ECNZ properties had protection memorials on their title. ${ }^{46}$ Waikato-Tainui advisors cautioned ECNZ that they should not proceed with the auction to sell the properties but ECNZ did not heed their warnings. After receiving no bids ECNZ offered the properties to the Crown for inclusion in the Waikato-Tainui land-bank. ${ }^{47}$ The land-banking of the ECNZ surplus assets was supported by Treasury but only because of the advanced nature of Waikato-Tainui's negotiations with the Crown. Some officials from Treasury attempted to argue that because the bulk purchase had resulted in the Crown purchasing at half the value, the Crown should receive some kind of compensation. ToWPU officials were clearly unimpressed by the idea:

Such an approach is inconsistent with the principles for land banking and with the proposed operation of the Treaty of Waitangi Settlement Fund. The cap on the land bank provides incentives for the claimants to select properties up to its value on the basis of the sum of the prices paid for those properties. Claimants carry the risk that the properties will reduce in value while in the land bank. The Crown loses nothing if the properties increase in value. We consider to impose a charge against the cap on the land bank of any more than the price paid by the Crown would be an act of bad faith. $^{48}$

ToWPU officials obviously felt strongly about the issue and successfully countered Treasury.

Once the land-bank was established the TMTB slowly evaluated surplus Crown properties for inclusion in the land-bank. Graham complained in a letter to Mahuta regarding the delays in evaluating properties. Mahuta responded that the Crown had provided incomplete information with regards to the extent of the Crown's asset base in the Waikato-Tainui rohe. In June 1993 the Crown enquired whether Waikato-Tainui sought to add certain properties into the land-bank. Mahuta wrote a frustrated reply to ToWPU officials:

Given the current state of confusion, maybe all housing stock should go into the Landbank before we are pestered to make decisions based on scanty information.... As you can see from the tenor of this note, I came out of my meeting with the Minister feeling somewhat annoyed that matters have not really progressed very far. If the Crown has no intention to settle with Waikato then perhaps that needs to be said so that we can all reassess our positions. We are incurring too much time, energy and costs on nonfruitful endeavours. ${ }^{49}$

In 1994 Mahuta continued this argument and emphasised the Crown's lack of funding for evaluating surplus properties for land-banking which had inhibited the TMTB's other operations. Mahuta added that it was "important from the TMTB's perspective (and in the 
longer term that of the Crown) to ensure it is assets rather than liabilities which are being landbanked. The Hopuhopu and Te Rapa experiences are a constant reminder of this. Accordingly, prudence suggests that the Board must and will continue to be careful in its scrutiny of properties to be transferred." ${ }^{50}$ Mahuta noted that without any type of agreement on the implementation of the settlement the "exercise has something of the ring of shuffling paper from one government department to another." Mahuta stated that it was important to WaikatoTainui, and from Mahuta's point of view also for the Crown, that properties with liabilities not be used in the settlement. This would simply represent a repetition of history similar to the return of lands by the Compensation Court in the nineteenth century after the original confiscation of land when mainly unusable land was returned. ${ }^{51}$

As the Crown continued to raise concerns with the delays in Waikato-Tainui's evaluation of properties, Mahuta continued to express his concern with the quality of Crown properties offered for inclusion. Graham stressed that Waikato-Tainui did not have to approve each and every property. Henare pointed out that Waikato-Tainui's concerns with Graham's recommendation was the potential for an unsuccessful negotiation in which Waikato-Tainui acquiesces to the disposal of land. Graham countered that it was not only surplus properties which could be used in any settlement, but any properties in the Crown's dossier. This changed the situation as it was different from anything discussed previously. Mahuta took this point one step further and asked whether non-Crown lands would be available for purchase with settlement funds, which Graham confirmed. This was necessary because of the significant liabilities which most properties in the Crown dossier carried. ${ }^{52}$

The return of land was a central component in the Waikato-Tainui negotiation process. While some Crown lands were offered for return, lands from the DoC estate were excluded. Waikato-Tainui was focused on not only the return of land, but also ensuring the land that was transferred could be retained. Waikato-Tainui negotiators and advisors advocated for the return of land under customary title, rather than the fee simple title that was proposed, and also sought the return of lands that were not subject to marginal strips. Waikato-Tainui were concerned that their land settlement would not affect their claims to the Waikato River and West Coast Harbours that had been separated early in the negotiations. These issues reflected WaikatoTainui's overriding concerns with the return and retention of land under circumstances that would enhance the rangatiratanga of the iwi in the Waikato.

\section{Waikato-Tainui and the return of DoC land}

DoC's involvement in the Waikato-Tainui negotiations was limited since the settlement would only address issues regarding the confiscation of land, rather than specific conservation sites. Nonetheless, Waikato-Tainui sought land from the conservation estate or, if the return of DoC land was not possible, then a co-management role in DoC areas. ${ }^{53}$ There was just over 55,000 acres of DoC lands in the Waikato raupatu rohe. ${ }^{54}$ Late in the negotiations Mahuta attempted to have full title to the DoC estate included in the settlement. Those DoC lands would then be leased back to the Crown at peppercorn rentals which would be reviewed every 25 years. Mahuta stated in a letter to Graham: "It is not the intention to develop Conservation lands. We are however, interested in joint management of the estate and the jobs or training opportunities that might arise. Such an arrangement would satisfy our 'Land for Land' principle while at the same time meet the Crown's desire to maintain the lands for public use and access." WaikatoTainui negotiators stressed that international examples of co-management regimes in Australia and Canada had provided precedents and would be valuable to use in the New Zealand context. ${ }^{55}$ Furthermore, Waikato-Tainui condemned the Crown's own record of conservation and alluded to the poor job it had done in the Waikato region to that date. Waikato-Tainui stressed that the iwi would work with involved stakeholders such as conservation boards and regional and local authorities and would strive to enhance the conservation value of the lands 
as well as the public's access to them. ${ }^{56}$ Graham stated that the conservation estate was not available and instead offered Waikato-Tainui representation on the Waikato Conservation Board.$^{57}$ The issue of the DoC estate was consistently brought up during the consultation process by both supporters and opponents of Mahuta within Waikato-Tainui. It was a very important issue for the iwi that could have derailed the settlement because Waikato-Tainui wanted an increased kaitiaki role in the overall management of the DoC estate. ${ }^{58}$

The DoC position was very firm although it was challenged by ToWPU. The lead ToWPU official on the Waikato-Tainui negotiations tried to work with DoC, but they maintained their opposition. The Director-General of DoC replied to ToWPU inquiries regarding the use of the conservation estate in either the transfer of land or co-management, that there were significant and wide ranging implications if any of the conservation estate was transferred to Waikato-Tainui, even if DoC lands were immediately gifted back. The DirectorGeneral referred to the difficulties involved in the return of Mount Hikurangi to Ngāti Porou. Issues regarding public access to Mount Hikurangi following its return to Ngāti Porou made the Director-General apprehensive. He pointed to the spectre of co-management with Māori claimants and questioned whether the Crown or public was ready for such a change. He also referred to the potential negative effect on "investment security for businesses." 59 DoC's position in Cabinet prevailed, and there was no involvement from DoC in Waikato-Tainui's settlement. ${ }^{60}$

At the time there was no policy on the return of conservation lands since the 1989 Principles on Crown Action on the Treaty of Waitangi consisted of general directives rather than specific policy positions and the 1990 booklet produced by the Treaty of Waitangi Policy, The Direct Negotiation of Māori Claims, had nothing specific on conservation either. But the Crown Proposals for the Settlement of Treaty of Waitangi Claims were under development during the Waikato-Tainui negotiations and were released two weeks before the Heads of Agreement was signed on 21 December 1994. The 1994 Crown Proposals provided for the return of specific and discrete conservation lands that claimants could prove had cultural significance. A year and a half later when Ngāi Tahu signed their Heads of Agreement just over 500 acres of DoC lands around the South Island were returned as a part of the Ngāi Tahu settlement. The use of DoC lands in Treaty settlements have particularly increased since 2008 and the direction of policy under Minister of Treaty of Waitangi Negotiations Christopher Finlayson. ${ }^{61}$

\section{Waikato-Tainui's desire for customary title}

The legal form in which lands would be returned also troubled Waikato-Tainui negotiators and advisors. Legal advisor Denese Henare felt that special legislation specifically vesting returned land into Waikato-Tainui was necessary. When the parties were approaching a Heads of Agreement in late 1994 and it became apparent that further lands in addition to Hopuhopu and Te Rapa would be transferred, Henare again pressed for special arrangements to govern the return of land to Waikato-Tainui. Henare corresponded with ToWPU officials about the possibility of the return of land under customary title that would not be governed by the provisions of the Public Works Act. Henare feared that Waikato-Tainui would not have absolute control over its land if it was subject to possible future confiscation of land through administrative means such as public works takings. ToWPU officials had raised the issue of customary title with Graham but he did not believe the concept could be used. Graham repeated his opposition publically at a February 1995 academic conference on Treaty settlements held in Wellington. Henare had wanted to engage in formulating relationships between rangatiratanga and the statutory and regulatory powers of central and local government, but the traditional aversion by the New Zealand government to any delegation of sovereignty was paramount. $^{62}$ 
Although Graham had rejected the suggestion of placing the land being returned to Waikato-Tainui in a form of tribal or customary title, Henare and Waikato-Tainui junior legal advisor Shane Solomon still sought ways to instil into the proposed legislation the special spirit and intent of this particular transfer of land from the Crown. Solomon looked to the developments in Australia with regards to native title at both the federal and state levels for inspiration but admitted that the Crown would probably oppose such proposals. In terms of conservation land Waikato-Tainui negotiators had fought for the Australian "Uluru" model, but the Crown rejected the model. ${ }^{63}$ The Crown offered a reserved position on the Waikato Conservation Board. Solomon wanted the legislation that governed the returned land to reflect the tenure of the land as it was in 1863-something Solomon admitted was very difficult:

What is being sought there is the nature of the "ownership" back in 1863-65. There should be no confusion that we are seeking the lands to be returned in the state they were in back then - ie the University lands to be returned with no improvements. The "ownership" issue relates to the vesting of the lands under the Kingiitanga, thus the compulsory taking of those lands by the Crown. It also relates to the tribal interest in the lands. Prior to the wars and confiscations, lands vested in Te Wherowhero (subsequently reaffirmed through the years). The Confiscations removed lands away from both the kingiitanga [sic] and therefore the Tribe. Today, the return of the lands must benefit all of the tribe who suffered, not just those who are fortunate enough to have Crown owned lands left to settle the grievance. The vast majority are not so fortunate. ${ }^{64}$

The debates over the form in which land would be returned and to which organisation the land would be returned remained pressing throughout the negotiation process. During a February 1995 meeting with Waikato-Tainui advisors, Crown officials expressed their concern that if certain lands were rendered inalienable, it would affect the iwi's commercial flexibility following settlement. Waikato-Tainui financial advisors countered that although it would not be possible to mortgage inalienable land, the income from valuable leases could still be mortgaged. Waikato-Tainui advisors stated that the inalienable status of the land provided comfort to the people that the returned lands would remain in the ownership of the iwi. ${ }^{65}$

Mahuta also discussed the issue of a special title over lands returned with Graham directly during the period of negotiations between the signing of the Heads of Agreement in December 1994 and the Deed of Settlement in May 1995. After consideration by Graham, he maintained that land could be put into Te Wherowhero title as Hopuhopu and Te Rapa were, but that the land would still be in fee simple title, not any kind of "customary" title. Mahuta also was concerned about other land issues - the imposition by the Crown of marginal strips, and the desire by Waikato-Tainui to maintain the protective Treaty of Waitangi (State Enterprises) Act 1988 memorials on land along the Waikato River. ${ }^{66}$

\section{Marginal strips}

Waikato-Tainui's concerns with the manner in which land was returned led to Waikato-Tainui negotiators expressing their reservation with the return of land accompanied by marginal strips. Waikato-Tainui negotiators viewed marginal strips as another form of confiscation. The Crown was adamant that marginal strips would remain adjacent to former SOE lands along the river and foreshore, even after the protection memorials were lifted and the land possibly transferred to Waikato-Tainui. OTS explained to Waikato-Tainui legal advisor Denese Henare that when the lands were first transferred to a SOE a marginal strip was imposed. The marginal strip would remain even after the land was disposed of privately by the SOE or via transfer to Waikato-Tainui in any Treaty settlement. OTS stated that for other non-SOE lands the Crown still retained the right to create a marginal strip whenever it disposed of land: " $[\mathrm{M}]$ arginal strips 
will be imposed, where relevant, when the Crown transfers land to [Waikato-]Tainui under the settlement." 67

The Waikato-Tainui opposition to marginal strips was so strong that the Deed of Settlement noted Waikato-Tainui's concerns. The Crown would maintain its power to retain and create marginal strips, but it agreed to record Waikato-Tainui's dissent. Section 5.4.3 of the Deed of Settlement stated: "That the Crown recognises that the issue of the creation of marginal strips on land to be transferred to the Land Holding Trustee is of serious concern to Waikato." The settlement clause noted further that "the Crown acknowledges that Waikato intend to advance their concerns about the creation of marginal strips to the Minister of Conservation." 68 Waikato-Tainui continued to express their opposition to the imposition and retention of marginal strips during the Māori Affairs Select Committee Hearings before legislation was passed in November $1995 .{ }^{69}$ Waikato-Tainui were unsuccessful in advancing their concerns about the creation of marginal strips with the Minister of Conservation, and the issue would remain to be negotiated in Waikato-Tainui's Waikato River Treaty Settlement. ${ }^{70}$

\section{The removal of protection memorials on SOE lands along the Waikato River}

Another concern regarding the return of land for Waikato-Tainui negotiators was the separation of their land claim from Waikato-Tainui claims to the Waikato River and the three West Coast Harbours: Aotea, Kawhia and Whaingaroa (Raglan). ${ }^{71}$ The River especially had been discussed at various times throughout the negotiation in the early 1990s but by 1994 it was clear that the River and the Harbours would be dealt with separately to facilitate an earlier settlement of the raupatu claim. It is unclear if Waikato-Tainui would have preferred to have all its claims settled at once if that realistically been a choice. Some settlements in more recent times that encompassed major water bodies have involved the separation of those claims from land-based claims such as the various iwi settlements for the Waikato, Waipa and Whanganui Rivers and the Te Arawa Lakes. ${ }^{72}$ The Crown wanted to have the Treaty of Waitangi (State Enterprises) Act 1988 protection memorials removed from State Owned Enterprises (SOE) lands along the Waikato River. ${ }^{73}$ Waikato-Tainui were concerned that their claim to the Waikato River was unjustly being affected by their land claim. Waikato-Tainui stated that retaining the memorials on river-side SOE properties was integral to the river and harbours claim, but the Crown contended that the memorials would be removed from the titles of SOE lands along the river by their land settlement. Waikato-Tainui felt that the rangatiratanga of their river and harbours claim was being challanged by the Crown. ${ }^{74}$ Late in the negotiation process, only weeks before the signing of the Deed of Settlement, Mahuta requested that the memorials remain on the SOE properties along the Waikato River but Graham refused. Despite Waikato-Tainui's objections, Graham stated that the memorials would be removed from the SOE properties along the river. ${ }^{75}$ The Crown's position on the memorials for the river-side SOE properties led to further Waikato-Tainui concerns about their continuing Treaty of Waitangi rights to the river and harbours.

Despite Graham's public assertions that settlements were intended to fulfil the Crown's obligations under the Treaty of Waitangi rather than erase or undermine them, Waikato-Tainui negotiators still wanted to ensure that the Crown's obligations under the Treaty of Waitangi continued after settlement. ${ }^{76}$ Waikato-Tainui felt that their land-based raupatu settlement would only extinguish Waikato-Tainui's Treaty of Waitangi rights in relation to the grievance of raupatu. Waikato-Tainui legal advisors wrote to ToWPU officials:

This settlement is a limited recognition of the Crown's obligations by way of redress (the return of land) for the specific injustice of the Raupatu, and those special rights (the rangatiratanga of Waikato under the Treaty) are not, and must not, be affected by this Settlement. The danger to Waikato of not making specific reference in this Deed to the rangatiratanga of Waikato under the Treaty is that Waikato is open to an 
argument, at some time in the future, that this Settlement is a settlement of Waikato's rangatiratanga, that Waikato has accepted a position which limits Waikato's rangatiratanga to a return of land. ${ }^{77}$

The issue of finality was still a large concern for Waikato even though the river and harbours had been excluded from their claim. Mahuta stressed to Graham in an early May 1995 meeting that the issue of the Crown's affirmation of Waikato-Tainui's rangatiratanga, especially in relation to Waikato-Tainui claims to the Waikato River and West Coast Harbours, had repeatedly been raised at consultation hui and that it was important to whether or not the settlement was accepted. In response to concerns about rangatiratanga rights, the Crown had amended the draft final deed of settlement to specifically state that the settlement would not diminish the Treaty of Waitangi or any of its articles but Mahuta stressed that this did not go far enough for Waikato-Tainui negotiators. ${ }^{78}$

The inclusion of the direct reference to rangatiratanga rights remained a problem even after the Deed of Settlement was signed on 22 May 1995, as discussions occurred in July 1995 just before the first draft of the legislation was introduced to Parliament. Waikato-Tainui legal advisor Gerard Brown questioned why the inclusion of rangatiratanga rights was unacceptable to the Minister? Crown officials replied, much as they did to Ngāi Tahu when they were negotiating with the Crown over the development of their legal personality, that the term was undefined and that it would "introduce uncertainty into the Deed of Settlement."79 Eventually the Crown agreed during the meeting to include the reference to rangatiratanga rights as a part of the detailing of the Treaty of Waitangi at the beginning of the settlement legislation. Nonetheless, the first draft of the legislation contained the Treaty of Waitangi only in English in the preamble and thus there was no direct reference to rangatiratanga. The final legislation contained the Treaty of Waitangi in both English and Māori. A direct reference to rangatiratanga and Waikato-Tainui's claims to the River remained, even if the protection memorials on the titles of lands across the River did not. ${ }^{80}$

\section{Conclusion}

The return of land to Waikato-Tainui was an important part of their Treaty settlement. Waikato-Tainui's focus on the return of land as the central component of their settlement was emblematic of their desire to have the maximum amount of land returned. This focus also reflected the specific context of Waikato-Tainui's negotiations, since their settlement was restricted to the return of land rather than other conservation issues. Waikato-Tainui sought mechanisms to retain the land and pushed for a form of customary title under which returned lands would be inalienable. Waikato-Tainui was concerned regarding the continuing alienation of Crown lands in its tribal rohe during the negotiations. The development of a protection mechanism to allow Waikato-Tainui the opportunity to reserve certain Crown lands for use in a future settlement, the land-bank, slowed the alienation of Crown land but it was only established four years after it was first developed by Crown officials. Ngāi Tahu were able to have a land-bank established in 1990 and perhaps the weight and backing of the Waitangi Tribunal was vital, which released reports into the Ngāi Tahu claim from 1991. During the closing hearings Presiding Officer Judge Ashley McHugh asked the Crown to develop a system for protecting Crown lands from alienation. A nation-wide Protection Mechanism Scheme for the protection of Crown land came into place in 1993; it is unclear from the evidence available if it had any impact on the establishment of the Waikato-Tainui land-bank. The Waikato-Tainui land-bank system was not perfect, it came four years after it was proposed and it often frustrated Waikato-Tainui, but it was an innovative method to protect at least some Crown lands from alienation. 
In the late-nineteenth century King Tawhiao had laid down the basis for resolving Waikato-Tainui grievances regarding the confiscation of land: as land was taken, so land must be returned. The 1995 settlement fulfilled that condition in part: not all Crown lands were returned, and they were often not returned under the title arrangements preferred by WaikatoTainui. The Crown controlled the parameters and limits of the process, but nonetheless at long last some land was finally returned. As a significant land-owner in the Waikato, the iwi has expanded its political and economic influence both regionally and nationally. Even if some lands still remain in Crown ownership in the Waikato confiscation rohe, the reclamation of Waikato-Tainui's turangawaewae (or place to stand) has been given a significant boost.

\footnotetext{
${ }^{1}$ Claudia Orange, An Illustrated History of the Treaty of Waitangi (Wellington: Bridget Williams Books, 1987), 39.

${ }^{2}$ Hirini Moko Mead and Neil Grove, Ngā Pēpeha a ngā Tipuna (Wellington: Victoria University Press, 2001), 266, 405.

${ }^{3}$ Paerau Warbrick, "'O ratou wenua': Land and Estate Settlements," in Treaty of Waitangi

Settlements, ed. Nicola Wheen and Janine Hayward (Wellington: Bridget Williams Books, 2012), 92.

${ }^{4}$ Michael J. Stevens, "Settlement and Taonga," in Treaty of Waitangi Settlements, ed. Wheen and Hayward, 124-25.

${ }^{5}$ Waikato-Tainui Raupatu Claims Settlement Act 1995.

${ }^{6}$ Marginal strips are strips of land, usually 20 metres wide, which extend along and abut the landward margins of parts of the foreshore and the beds of other water bodies. Marginal strips are created when the Crown disposes of land. http://www.linz.govt.nz/survey-titles/cadastral-
}

surveying/publications/marginal-strips.

${ }^{7}$ NZMC v. Attorney-General (1987); Orange, An Illustrated History, 164-66; Alan Ward, An

Unsettled History (Wellington: Bridget Williams Books, 1999), 37-38; Michael King, Penguin

History of New Zealand (Auckland: Penguin, 2004), 501.

${ }^{8}$ Treaty of Waitangi (State Enterprises) Act 1988.

${ }^{9}$ Damian Stone, "The Financial and Commercial Dimensions," in Treaty of Waitangi Settlements, ed. Wheen and Hayward, 141-42.

${ }^{10}$ Ward, An Unsettled History, 36.

115 March 1990 meeting (Crown version), TC 30 Vol. 7, OTS archive.

${ }^{12}$ Robert Mahuta to Jim Bolger, 24 June 1991, AAKW W5105 7812 26, Archives NZ; Bolger to Mahuta, 19 July 1991, RC Vol 5, Box 8, W-T archives; Mahuta to Douglas Graham, 31 July 1991, TC30 Vol. 13, OTS archive.

${ }^{13}$ Interview with Sir Douglas Graham, 22 May 2011.

${ }^{14}$ ToWPU official 4, 22 January 1992; DoSLI official 1 to ToWPU official 4, 3 March 1992, TC30 Vol. 16 \& 19, OTS archive.

${ }^{15}$ ToWPU official 4 to Mike Ashby, 21 January 1992, TC30 Vol. 16, OTS archive.

${ }^{16}$ Vincent O'Malley, The Great War for New Zealand: Waikato 1800-2000 (Wellington: Bridget Williams Books, 2016), 215-346.

${ }^{17}$ In 1927 the Sim Commission, established largely at the urging of Māori MPs Maui Pomare and Apirana Ngata, released a report which found that the confiscation of land in the Waikato (and elsewhere) was excessive but justified. It recommended financial compensation. Negotiations with the government began in the 1930s, and by 1946, Waikato-Tainui were granted a small amount of annual compensation, $£ 5,000$ annually for thirty years, under the Waikato-Maniapoto Claims Settlement Act that was eroded over the years by inflation. The legislation also established the Tainui Māori Trust Board, which managed and distributed the annual compensation. Most Waikato-Tainui leaders were not satisfied with the token annual sum and the fact that the agreement did not include the return of land (and did not agree that the confiscation was justified), while successive governments considered that the compensation provided was a full and final settlement. Some Waikato-Tainui leaders continued to pursue a more robust settlement of their claims against the government that included land. See Michael King, Te Puea: A Life (Auckland: Penguin, 1977), 222-25; Robert Mahuta, 
"Tainui, Kīngitanga and Raupatu," in Justice \& Identity: Antipodean Practices, ed. Margaret Wilson and Anna Yeatman (Wellington: Bridget Williams Books, 1995), 25-28; David McCan, Whatiwhatihoe: The Waikato Raupatu Claim (Wellington: Huia, 2001), 181-216; Richard Hill, State Authority, Indigenous Autonomy: Crown-Māori Relations in New Zealand/Aotearoa 1900-1950 (Wellington: Victoria University Press, 2004), 223-24; Cathy Marr, "Crown Policy Towards Major Crown-Iwi Claim Agreements of the 1940s and 1950s: A Preliminary Report for the Treaty of Waitangi Policy Unit," 2010; Michael Belgrave, "Negotiations and Settlements" in Treaty of Waitangi Settlements, ed. Wheen and Hayward, 45.

${ }^{18}$ DoSLI official 2 to Alex Frame, 4 October 1990, TC30 Vol 9, OTS archive; AJ Clarke to Mahuta, 13 June 1991, RC Vol 5, Box 8, W-T archive; Kirsty Babbington, "Tainui Battle Took 100 Years," Waikato Times, 7 September 1991, TC30 Vol.14 OTS archive; Jean Rhodes, "Hopuhopu Land Deal," 7 September 1991, Waikato Times; Ross Baker to Bolger, 1 September 1991; Bolger to Baker, 27 September 1991: all TC30 Vol.14, OTS archive; John Luten to Graham, 28 July 1992, TC30 Vol 25, OTS archive.

${ }^{19}$ Mahuta, "Hopuhopu and Te Wherowhero," 1 August 1991, RC Vol 5, Box 8, W-T archives.

${ }^{20}$ Nicholas Flanders, "Lessons for the Māori from the Alaska Native Claims Settlement Act," undated; Charles K. Ray (University of Alaska) to Mahuta, 10 May 1985: Alaska folder, W-T archives; Flanders, "The Alaska Native Corporation as Conglomerate: The Problem of Profitability," Human Organisation 48, no. 4 (Winter 1989): 299-312.

${ }^{21}$ Shane Solomon, Meeting between Waikato-Tainui and ToWPU officials, 21-22 April 1994, RC Vol 33, Box 13, W-T archives.

${ }^{22}$ Mahuta to Denese Henare, June 1993, RC Vol 30 1993, Box 11, W-T archives.

${ }^{23}$ Berryman v Te Arikinui Te Atairangikaahu - Hopuhopu Military Camp and Te Rapa Airforce Base (1993), 18 Waikato Maniapoto Appellate MB 173.

${ }^{24}$ Berryman v Te Arikinui Te Atairangikaahu - Hopuhopu Military Camp and Te Rapa Airforce Base (1993), 18 Waikato Maniapoto Appellate MB 173.

25 "Base due to return to Tainui," Waikato Times, 28 November 1992, TC30 Vol. 26, OTS archive.

26 "Tainui Māori Trust Board meeting," 4 July 1992, RC Vol 11 1992, Box 11, W-T archive; Derek

Burns to Graham, 6 August 1992, TC30 Vol. 25, OTS archive; Mahuta to Henare, 22 October 1992,

RC Vol 29, Box 11, W-T archive.

${ }^{27}$ DoSLI official 4 to ToWPU official 4, 12 November 1992, TC30 Vol. 26, OTS archive.

${ }^{28}$ ToWPU official 4 to John Te Maru, 5 August 1993, RC Vol 31, Box 12, W-T archive.

${ }^{29}$ Berryman v Te Arikinui Te Atairangikaahu - Hopuhopu Military Camp and Te Rapa Airforce Base (1993), 18 Waikato Maniapoto Appellate MB 173, 3.

${ }^{30}$ Robert Joseph, "Unsettling Treaty Settlements: Contemporary Māori Identity and Representation Challenges," in Treaty of Waitangi Settlements, ed. Wheen and Hayward, 156-60. It should be said that the practical difficulties of negotiating with the thousands of hapu throughout New Zealand also influenced the Crown's preferences.

${ }^{31}$ Ngāti Whawhakia and Ngāti Wairere later appealed the Māori Appellate Court's decision to the High Court in June 1995 and the issue was not settled until the passing of settlement legislation that finally formally vested the lands in Te Wherowhero in late 1995: Ngapare Hopa to Graham, 28 November 1994, TC30 Vol.40, OTS archive; "Hopuhopu and Te Rapa," 27 June 1995, RC SS June to September 1995, Box 39, W-T archives; Bill Patterson to Graham, 22 September 1995 \& Mahuta to Graham, 25 September 1995, both: June to September 1995, Box 19, W-T archives; Graham to Mahuta, September to October 1995 (SS) Box 40, W-T archives.

32 John Te Maru, "Hopuhopu and Te Rapa," 23 September 1993, RC Vol 32, Box 12, W-T archives; Brent Wheeler to ToWPU official 4, 22 November 1993, RC Vol 32, Box 12, W-T archives.

${ }^{33}$ Solomon and Henare memoranda: RC Vol 33, Box 13, W-T archives; Meeting between Crown and Waikato negotiators, 14 April 1994, AAKW W5105 7812 22, Archives NZ; Mahuta to Graham, 10 February 1993, RC Vol 30 1993, Box 11, W-T archives, 1.

${ }^{34}$ Treasury official 1 to ToWPU official 3, 7 August 1989, TC30 Vol. 6, OTS archive.

${ }^{35}$ In the 1989 Coalcorp case Waikato-Tainui alleged that mineral wealth such as coal should equally be set aside by the Crown and used in a future settlement. Against the advice of most legal experts they filed an injunction in the Court of Appeal. The Courts once again backed the Māori claimants and instructed the government to halt the sale of Coalcorp assets in the Waikato so that they would b93 Journal of New Zealand Studies NS23 (2016), 19-36 
potentially available for Waikato-Tainui. See Tainui Māori Trust Board v. Attorney General (1989); Orange, An Illustrated History, 196-197; Hill, Mãori and State, 227.

${ }^{36}$ McCan, Whatiwhatihoe, 273-96.

${ }^{37}$ Bill Jeffries to Chairperson, Core Group of Officials, Crown Task Force on Treaty of Waitangi Issues, "Sale of Crown lands within Tainui raupatu," May 1990, TC30 Vol. 8, OTS archive.

${ }^{38}$ Just before the 1990 election Labour offered Waikato-Tainui a settlement that consisted of $\$ 10$ million in surplus Coalcorp properties, 60 house lots, 12 farm lots, a hostel and some other properties, without ownership of the coal, on top of the $\$ 8$ million that the Crown proposed to transfer to Waikato in arrears for payments to the Trust Board. The offer was rejected: TOW (90) 23, 31 July 1990, TC30 Vol.9, OTS archive; Jeffries to Mahuta, 6 August 1990, TC30 Vol.9, OTS archive; Jeffries to Mahuta, 15 October 1990, TC30 Vol.10, OTS archive. Last two also RC1, Vol.4, Box 7, W-T archives;

Mahuta to Jeffries, 19 October 1990, TC30 Vol.10, OTS archive \& RC1, Vol.4, Box 7, W-T archives; McCan, Whatiwhatihoe, 310-12.

${ }^{39}$ Henare to Doug Kidd, 5 June 1991, AAKW W5105 7812 26, Archives NZ; Henare to Graham \& Maurice McTigue, 8 November 1991, RC Vol 5, Box 8, W-T archives; Henare to McTigue, 13

November 1991, TC30 Vol. 16, OTS archive.

${ }^{40}$ Mahuta to Graham, 15 June 1992, TC 30 Vol. 23, OTS archive.

${ }^{41}$ Mahuta to Graham, 15 June 1992, RC Vol 11 1992, Box 11, W-T archives.

${ }^{42}$ Treasury official 9 to ToWPU official 4, 21 July 1992, TC30 Vol. 24, OTS archive; Minister of Justice to Cabinet Strategy Committee, "Proposals for an Early Waikato System for Tainui," 23 July 1992, TC30 Vol. 24, OTS archive. I have not been able to locate the Cabinet paper that rejects the proposals, but the system is not established until 1993 so it is clear Cabinet rejected the proposals earlier in 1992.

${ }^{43}$ The Right of First Refusal was a key part of the Waikato-Tainui raupatu settlement and all other settlements that have taken place. It provides the claimant group with the first right to purchase Crown lands as they become available for privatisation for a specific number of years: Waikato Tainui Raupatu Claims Settlement Act 1995, Section 10; Office of Treaty Settlements, Healing the past, building a future (Wellington: OTS, 2011), 84-85.

${ }^{44}$ Henare to Mahuta, 13 April 1993, RC Vol 30 1993, Box 11, W-T archives.

${ }^{45}$ CAB (93) 259; CAB (93) M 15/26; TOW (93) 6: AAKW W5105 7812 22, Archives NZ; Graham to Mahuta, 12 May 1993, RC Vol 30 1993, Box 11, W-T archive; Mahuta to Thomas, 20 May 1993, RC Vol 31, Box 12, W-T archive.

${ }^{46}$ Section 27B of the Treaty of Waitangi (State Enterprises) Act 1988 stated that if the Tribunal found that specific SOE land had been acquired in breach of the principles of the Treaty of Waitangi it could order the government to reacquire the land at market value and return it to the Māori claimants: Treaty of Waitangi (State Enterprises) Act 1988, Section 27B.

${ }^{47}$ Reuben Wharawhara, "Board Warns of land claims on ECNZ houses," Waikato Times, 7 August 1993; Mahuta to ToWPU official 4, 21 June 1993; ToWPU official 4 to John Te Maru, 17 August 1993, all: RC Vol 31, Box 12, W-T archives.

${ }^{48}$ ToWPU official 4 to Treasury official 9, 11 October 1993, AAKW W5105 7812 22, Archives NZ.

${ }^{49}$ Mahuta to ToWPU official 4, 21 June 1993, RC Vol 31, Box 12, W-T archives.

${ }^{50}$ Mahuta to Graham, 8 March 1994, AAKW W5105 7812 22, Archives NZ/RC Vol 33, Box 13, W-T archives.

${ }^{51}$ Mahuta to Graham, 8 March 1993, RC Vol 33, Box 13, W-T archives; Mahuta diary note, 10 March 1993, RC Vol 33, Box 13, W-T archives; Danny Keenan, Wars Without End (Auckland: Penguin, 2009), 264-82; Craig Innes and James Mitchell, "Alienation of Māori Granted Lands Within Te Rohe Pōtae Parish Extension, 1863-2011," Report Commissioned by the Waitangi Tribunal (Wai 898, \#A30), 2013.

${ }^{52}$ Solomon and Henare memoranda, 14 April 1994, RC Vol 33, Box 13, W-T archives; ToWPU, "Meeting between Crown and Waikato negotiators," 14 April 1994, AAKW W5105 7812 22,

Archives NZ.

${ }^{53}$ Wayne Taitoko to Mahuta, 7 October 1994, RC1, Correspondence Vol 35, Box 14, W-T archives.

${ }^{54}$ Mahuta to Graham, 25 October 1994, TC Vol. 38, OTS archive.

${ }^{55}$ Stacey Anne Shortall, "Aboriginal Self-Government in Aotearoa-New Zealand: a View Through the Canadian Lens" (unpublished master's thesis, University of Alberta, 1996).

Journal of New Zealand Studies NS23 (2016), 19-36 
${ }^{56}$ Mahuta to Graham, 4 November 1994, TC30 Vol. 39, OTS archive; Solomon to Mahuta, 7 November 1994, RC1, Correspondence Vol 36, Box 14, W-T archives.

57 "Meeting between Crown and Waikato negotiators," 26 October 1994, RC1, Correspondence Vol 35, October 1994, Box 14, W-T archives; "Meeting between Crown and Waikato negotiators," 26 October 1994, TC30 Vol. 38, OTS archive, 2; Mahuta to Graham, 26 October 1994, TC30 Vol. 38, OTS archive; Graham to Mahuta, 27 October 1994, RC1, Correspondence Vol 35, October 1994, Box 14, W-T archives.

${ }^{58}$ Wayne Taitoko to Mahuta, 7 October 1994, RC1, Correspondence Vol 35, Box 14, W-T archives; Mahuta to TMTB Maraes, 1 November 1994 and "Hui-a-Iwi," 13 November 1994, both: RC1, Correspondence Vol 36, Box 14, W-T archives.

${ }^{59}$ Director-General of DoC to ToWPU official 4, 18 November 1994, TC30 Vol. 40, OTS archive.

${ }^{60}$ CAB (94) M 49/30, TC30 Vol. 42, OTS archive.

${ }^{61}$ Most prominently Te Urewera Act 2014.

${ }^{62}$ ToWPU official 4, "Waikato negotiations," 13 December 1994, TC30 Vol. 41; ToWPU official 4 to Henare, 3 January 1995, RC1, Correspondence Vol 39, Mar - Apr 1995, Box 17, W-T archives; Shane Solomon, "Notes from conference," 9-10 February 1995, RC1, Correspondence SS, Jan - Feb 1995, Box 34, W-T archives; Doug Graham, "Address by the Minister in Charge of Treaty of Waitangi negotiations," in Unfinished Business, ed. Geoff McLay (Wellington: NZ Institute of Advanced Legal Studies, 1995), 141-47.

${ }^{63}$ In 1985 Ayers Rock or Uluru was returned as freehold title to the local Aboriginal community and leased back to the Australian government. Uluru is co-managed by a Park Board with an Aboriginal majority: David Lawrence, "Managing Parks/Managing 'Country': Joint Management of Aboriginal Owned Protected Areas in Australia," Research Paper 2 1996-97, Parliament of Australia.

${ }^{64}$ Solomon to Henare, 9 April 1995, RC Mar - Apr 1995, (SS) Box 35, W-T archives.

65 "Meeting between Crown officials and Tainui advisors,"16 February 1995, RC Jan-Feb, Box 16, W-T archives and NE-12-030-00-35, OTS archive.

${ }^{66}$ Mahuta, "Meeting notes," 14 April 1995, RC Vol 39, Mar - Apr 1995, Box 17, W-T archives.

${ }^{67}$ OTS Director to Henare, 3 April 1995, RC1, Correspondence March-April 1995 (SS) Box 37, W-T archives; Shane Solomon, "Telephone Conference," 18 May 1995; Mahuta, "Notes on Draft Deed of Settlement," 18 May 1995, RC1, Correspondence May 1995 Vol 40, Box 18, W-T archives.

${ }^{68}$ Waikato-Tainui Raupatu Deed of Settlement, 22 May 1995, Section 5.4.3.

69 "Waikato-Tainui Raupatu Claims Settlement Bill: Submissions on behalf of Waikato-Tainui," 25 August 1995, RC1, Correspondence June-September 1995 Vol 41 Box 19, W-T archives.

${ }^{70}$ Office of Treaty Settlements and the Ministry for the Environment, "Initial Departmental Briefing on the Waikato-Tainui Raupatu Claims (Waikato River) Settlement Bill," 9 February 2009, http://www.parliament.nz/resource/0000095966.

${ }^{71}$ Unlike nearly all other tribal-based settlements that followed, as the "first cab off the rank" Waikato-Tainui was able to separate its raupatu (confiscation) settlement from the rest of its claims.

${ }^{72}$ Waikato River (Waikato-Tainui) Deed of Settlement, 2010; Waikato River (Waikato-Tainui, Te Arawa Iwi, Ng āti T ūwharetoa, Raukawa) Deed of Settlement, 2010; Nga Wai o Maniapoto (Waipa River) Deed of Settlement, 2010; Ruruku Whakatupua: The Whanganui River Deed of Settlement, 2014.

${ }^{73}$ CLO official 4 to ToWPU official 4, 9 December 1994, TC30 Vol. 41, OTS archive.

${ }^{74}$ The CLO was worried that the inclusion of the term rangatiratanga in the legislation would suggest "that the exercise of rangatiratanga enables a future claim to be made over the raupatu lands" but OTS tried to assure CLO that was not the case: CLO official 4 to ToWPU official 4, 10 March 1995, NE12-030-00-35, OTS archive, 4.

${ }^{75}$ Treasury official 5 to Bill Birch, "Waikato-Tainui: Update on Heads of Agreement and expected progress from here,"20 January 1995, NE 10-030-00-02 pt.1, OTS archive; Tom Moke to Mahuta, 8 March 1995, RC Vol 39, Mar - Apr 1995, Box 17, W-T archives

${ }^{76}$ Graham, "Address by the Minister," in Unfinished Business, ed. McLay, 141-47.

${ }^{77}$ Gerard Brown to Waikato negotiators, RC1, 1 May 1995, RC Apr - May 1995, (SS) Box 36, W-T archives, 1. 
78 ToWPU official 4 to Gerard Brown, 3 May 1995, RC1, Correspondence May 1995 Vol 40 Box 18, W-T archives; Solomon to Te Maru, 3 May 1995, RC1, Correspondence May 1995, (SS) Box 38, WT archives; Mahuta to Graham, 4 May 1995, AAKW W5105 7812 23, Archives NZ.

${ }^{79}$ OTS official 4 to Graham, 10 July 1995, AAKW W5105 7812 22, Archives NZ.

${ }^{80}$ Henare to Solomon, 10 May 1995, RC1, Correspondence May 1995, (SS) Box 37, W-T archives; Niwa Nuri \& Solomon to Mahuta, 5 May 1995, RC1, Correspondence May 1995 Vol 40, Box 18, W$\mathrm{T}$ archives. 